\title{
Clinical implications of calcifying nanoparticles in dental diseases: a critical review
}

This article was published in the following Dove Press journal:

International Journal of Nanomedicine

10 December 2013

Number of times this article has been viewed

\author{
Mohammed S Alenazy' \\ Hezekiah A Mosadomi ${ }^{2,3}$ \\ 'Restorative Dentistry Department, \\ ${ }^{2}$ Oral and Maxillofacial Pathology \\ Department, ${ }^{3}$ Research Center, Riyadh \\ Colleges of Dentistry and Pharmacy, \\ Riyadh, Saudi Arabia
}

Background: Unknown cell-culture contaminants were described by Kajander and Ciftçioğlu in 1998. These contaminants were called nanobacteria initially and later calcifying nanoparticles (CNPs). Their exact nature is unclear and controversial. CNPs have unique and unusual characteristics, which preclude placing them into any established evolutionary branch of life.

Aim: The aim of this systematic review was to assess published data concerning CNPs since 1998 in general and in relation to dental diseases in particular.

Materials and methods: The National Library of Medicine (PubMed) and Society of Photographic Instrumentation Engineers (SPIE) electronic and manual searches were conducted. Nanobacteria and calcifying nanoparticles were used as keywords. The search yielded 135 full-length papers. Further screening of the titles and abstracts that followed the review criteria resulted in 43 papers that met the study aim.

Conclusion: The review showed that the existence of nanobacteria is still controversial. Some investigators have described a possible involvement of CNPs in pulpal and salivary gland calcifications, as well as the possible therapeutic use of CNPs in the treatment of cracked and/or eroded teeth.

Keywords: calcifying nanoparticles, nanobacteria, sialolith, pulp stone, enamel repair

\section{Introduction}

Unknown cell-culture contaminants were first described by Kajander and Ciftçioğlu in 1998. These contaminants were initially called nanobacteria, but were later renamed calcifying nanoparticles (CNPs). ${ }^{1}$ The nature of these entities was unclear, raising many controversial views as to whether they are indeed nanobacteria that replicate or simply inert nanocalcification. Many theories soon emerged, with each theory having its own enduring supporters. One theory, describes CNPs as the smallest-known replicating entities of organic life on earth, while other theories held that CNPs are mineral-protein complexes unrelated to bacteria. ${ }^{2-13}$ Sommer et al were of the opinion that nanobacteria have unique and unusual characteristics, which preclude placing them into any established evolutionary branch of life. ${ }^{14}$ Kajander et al presented a table that compared CNPs, virus, prions, and bacteria using over 20 characteristics or properties, as shown in Table $1 .{ }^{15}$ Despite the controversy on the true nature of CNPs, some authors have described some human diseases or conditions in which CNPs are associated as initiating or contributing agents (Table 2).

With the unresolved issue of what CNPs really are, a systematic review of informative published data on CNPs could suggest where and how to place CNPs in the scheme of things. The aim of this paper was therefore to perform a narrative systematic review of publications on CNPs since 1998 and highlight their hypothesized relationship with pulpal and salivary gland calcifications.
Correspondence: Mohammed S Alenazy PO Box 21437, Riyadh Colleges of Dentistry and Pharmacy, Riyadh II475, Saudi Arabia

Tel +966562608787

Fax +966 I2 468 7II

Email alenazy.endodontics@gmail.com submit your manuscript | www.dovepress.com

Dovepress

http://dx.doi.org//0.2147/IJN.S5 I538 
Table I Characteristics of CNPs compared with other types of cell

\begin{tabular}{|c|c|c|c|c|}
\hline Characteristics & CNPs & Viral & Prion & Bacteria \\
\hline Size & $50-300 \mathrm{~nm}$ & $20-250 \mathrm{~nm}$ & $<200 \mathrm{~nm}$ & $>250 \mathrm{~nm}$ \\
\hline Cell wall & CaP/atypical & No/protein layer & No & Yes \\
\hline Nucleic acids & Some, atypical & Yes, atypical & No & Yes \\
\hline Proteins & Yes & Yes & Yes & Yes \\
\hline Carbohydrates & Yes & Yes & Yes & Yes \\
\hline Self-replicating & Yes & No & No & Yes \\
\hline Growth in DMEM & Yes & No & No & Yes \\
\hline Resistant to $\gamma$-irradiation & $\sim 2.5 \mathrm{Mrad}$ & $<2.5 \mathrm{Mrad}$ & $>2.5 \mathrm{Mrad}$ & $<0 . \mathrm{I}->6 \mathrm{Mrad}$ \\
\hline Resistant to boiling temp & Yes & No/yes & Yes & No \\
\hline Resists antibiotics & No/yes & Yes & Yes & No/yes \\
\hline Sensitive to 5-FU & Yes & No & No & Yes/no \\
\hline Sensitive to CytAra & Yes & Yes & No & $?$ \\
\hline Sensitive to biophosphonates & Yes & No & No & No \\
\hline Immunogenic & Yes & Yes & No & Yes \\
\hline Cause inflammation & Yes & Yes & No & Yes \\
\hline Lipopolysaccharide (LPS) & Yes & No & No & Yes \\
\hline Host cell death & Yes & Yes & Specific & Some \\
\hline Pathologic calcification & Yes & A few & No & A few \\
\hline Biofilms & Yes & No & No & A few \\
\hline $\mathrm{CHD}$ association & Yes & Some & No & Some \\
\hline Stroke association & Yes & Some & No & Some \\
\hline Affects blood clotting & Yes & Some & No & Some \\
\hline Prothrombinase activity & Yes & No & No & Some \\
\hline PDL disease association* & Yes & No/yes & No & Yes \\
\hline Dental pulp stone* & Yes & No & No & No \\
\hline
\end{tabular}

Note: Data from Kajander et al. ${ }^{15}$ *Added by the author (MA).

Abbreviations: CNPs, calcifying nanoparticles; DMEM, Dulbecco's Modified Eagle's Medium; 5-FU, 5-fluorouracil; CytAra, Cytarabine; CHD, coronary heart disease; PDL, periodontal ligament.

\section{Materials and methods}

Medline (PubMed) and Society of Photographic Instrumentation Engineers (SPIE) electronic and manual searches were conducted. Nanobacteria and calcifying nanoparticles were used as keywords to extend the search to all the potentially relevant articles. The search yielded 135 papers, which were screened in detail. For review purposes, 92 papers were excluded and the remaining 43 papers that were most relevant to the aim of the study were reviewed.

\section{Results}

\section{Are CNPs living particles} or physiological contaminations?

The smallest possible size reported for self-replicating lifeforms is $140 \mathrm{~nm} .{ }^{16}$ Glass et al, ${ }^{17}$ claimed that Mycoplasma laboratorium could reach even smaller sizes. Based on these reports, it would seem that size alone could not be used to determine whether CNPs are life-forms or not. Other characteristics of life-forms that have been attributed to CNPs, as shown in Table 1, support the view that CNPs are not inert nanocalcifications.
The morphological properties of CNPs, which have been examined and described in many studies, are as follows:

- diameter ranges from 80 to $500 \mathrm{~nm}^{1,2}$

- morphological appearance is expressed in several shapes of coccoid, coccobacillar, or bacillar ${ }^{1,2,18}$

- shell structure - hydroxyapatite, cellular membranous, and central cavity 1,2

- colony formation - colonies $0.1 \mathrm{~mm}$ in size are grown in low-nutrient concentration environment ${ }^{1,2}$

- binary fission - division by binary fragmentation and gemination $^{1,2}$

- thermoresistant biofilms - resistance to high temperature. ${ }^{1,2}$

Several studies have used monoclonal antibodies to detect putative specific proteins of CNPs by cross-reaction methods and their role in several diseases in medicine and dentistry, is shown in Table 2. Other investigators - Martel and Young, ${ }^{9} \mathrm{Wu}$ et al, ${ }^{6}$ and Raoult et a ${ }^{10}$ - did not obtain the same result when they used the same method. Anti-CNP monoclonal antibodies have high sensitivity and low specificity, which explains the failure to achieve cross-reactions with serum protein (albumin and fetuin-A) in other studies. 
Table 2 Associations of CNPs with several human diseases

\begin{tabular}{|c|c|c|c|}
\hline Study & Sample source & Associations of CNPs & Specialty area \\
\hline Kajander et al ${ }^{19}$ & Blood serum & Pathological calcification & Medicine \\
\hline Ciftçioğlu et al ${ }^{20}$ & Pulp stone & Dental pulp stone & Dentistry \\
\hline Ciftçioğlu et $a^{2 !}$ & Kidney stones & Kidney-stone formation & Medicine \\
\hline Hjelle et $a^{22}$ & Cyst fluid and urine from PKD & PKD & Medicine \\
\hline Ciftçioğlu et a ${ }^{23}$ & Hypothesis & Periodontitis and PAD & Dentistry \\
\hline Miller et $\mathrm{a}^{24}$ & Calcified heart tissues & Vascular calcification & Medicine \\
\hline Ciftçioğlu et al ${ }^{25}$ & Randall's plaques & Kidney-stone formation & Medicine \\
\hline Zhou et $\mathrm{a}^{26}$ & Urine from patients with prostatitis & Type III prostatitis & Medicine \\
\hline Candemir et $\mathrm{a}^{27}$ & Calcified aortic heart valves & Vascular calcification & Medicine \\
\hline Hu et $a^{28}$ & Blood serum & Vascular calcification & Medicine \\
\hline Jing et $\mathrm{al}^{29}$ & Hypothesis & Repair enamel & Dentistry \\
\hline Schwartz et $\mathrm{al}^{30}$ & Calcified tissues & Arterial injury & Medicine \\
\hline Yang et $\mathrm{a}^{31}$ & Human dental pulp cells & Dental pulp stone & Dentistry \\
\hline Zeng et $\mathrm{a}^{18}$ & Dental pulp stone & Dental pulp stone & Dentistry \\
\hline Hudelist et $\mathrm{al}^{32}$ & Psammoma bodies & Psammoma body formation & Medicine \\
\hline Demir $^{33}$ & Hypothesis & Periodontal diseases & Dentistry \\
\hline Lin et $\mathrm{a}^{34}$ & Hypothesis & Repair cracks on enamel & Dentistry \\
\hline Shiekh et $\mathrm{al}^{35}$ & Renal tubular calcification & Renal calcification & Medicine \\
\hline Lu et $\mathrm{al}^{36}$ & Calcified placental tissues & Placental calcification & Medicine \\
\hline
\end{tabular}

Abbreviations: CNPs, calcifying nanoparticles; PKD, polycystic kidney disease; PAD, peripheral artery disease.

The method detects antigen present from bacterial prions and peptidoglycans in CNP structures. Calcifying NP antigens and antibodies were detected significantly more often in CNP-containing diseases compared to controls. ${ }^{2}$

Although many studies ${ }^{5-8,10}$ proposed that CNPs might have the ability to form mineral-protein complexes in normal serum in physiological conditions, in reality, Kajander et al reported that this could not be totally true. ${ }^{37}$ However, mineral-protein complexes have been shown in a gammairradiated serum study model by Martel and Young. ${ }^{9}$ The CNPs may replicate clearly in the absence of serum, as shown by Mathew et al, ${ }^{38}$ which demonstrated that replication of CNPs could occur independently of serum protein.

Decoding of CNP genomic constitution is still under investigation. Investigations have reported positive results with different deoxyribonucleic acid (DNA)-staining techniques of CNPs (Tables 3 and 4). One author was of the opinion that nucleic acids can be attracted to the highly charged proteins and molecules (shell-mineral-protein complexes), and that these are not produced in CNPs. ${ }^{3}$ Investigators used direct DNA-staining techniques on demineralized CNPs, which precluded a simple binding at the mineral-protein

Table 3 RT-PCR for the detection of CNP genomic contents

\begin{tabular}{lll}
\hline Study & Test type & Result \\
\hline Hudelist et $\mathrm{al}^{32}$ & RT-PCR & Nucleic acids \\
${\text { Kumar et } \mathrm{al}^{39}}$ & \\
\hline
\end{tabular}

Abbreviations: CNP, calcifying nanoparticle; RT-PCR, reverse-transcription polymerase chain reaction. shell (Table 5). In another report, contamination by other bacteria, eg, Phyllobacterium myrsinacearum, was presumed possible. $^{13}$

Ciftçioğlu et a $\mathrm{l}^{40}$ described morphological changes of CNPs caused by antimicrobial drugs under electron microscopy. In addition, they demonstrated the inhibition of CNP replications by aminocaproic acid, potassium citratecitric acid solutions, and 5-fluorouracil.

Data from a couple of investigations have indicated the absence of bacterial protein in demineralized CNPs, ${ }^{9,41}$ while others have shown the presence of bacterial proteins that might be due to replication, the protein-synthesis system, or bacterial metabolic process. ${ }^{39,35,36}$

Many findings and data oppose the hypothesis that CNPs are mineral-protein complexes. Although the formation of complexes of minerals and protein serum and other biological liquid under homeostasis was proposed by Martel and Young, Wu et al, ${ }^{6}$ Young et al, ${ }^{7,8}$ and Raoult et al, ${ }^{10}$ Kutikhin et al ${ }^{2}$ believed that the presence of CNPs in an organism is clearly a pathological process. In addition to their pathogenicity, these proteins may have a specific immunological reaction in forming specific antibodies.

Table 4 Indirect technique by $\left[{ }^{36} \mathrm{~S}\right]$ methionine and $\left[{ }^{3} \mathrm{H}\right] \mathrm{L}$-aspartic acid confirming CNP specific protein

\begin{tabular}{lll}
\hline Study & Test type & Result \\
\hline Kajander et $\mathrm{al}^{37}$ & Indirect technique: & Protein \\
Puskás et $\mathrm{al}^{42}$ & {$\left[{ }^{36} \mathrm{~S}\right]$ methionine and } & biosynthesis \\
& {$\left[{ }^{3} \mathrm{H}\right]$ L-aspartic acid } & \\
\hline
\end{tabular}

Abbreviation: CNP, calcifying nanoparticle. 
Table 5 Direct technique test of uridine $5-{ }^{3} \mathrm{H}$ incorporation into CNP nucleic acids

\begin{tabular}{lll}
\hline Study & Test type & Result \\
\hline Ciftçioğlu et $\mathrm{al}^{21}$ & Incorporated & Usage of $5-{ }^{3} \mathrm{H}$ in CNP \\
Khullar et $\mathrm{al}^{41}$ & uridine- $5-{ }^{3} \mathrm{H}$ & nucleic acids \\
Miller et a ${ }^{24}$ & & \\
Kumar et a ${ }^{39}$ & & \\
\hline
\end{tabular}

Abbreviation: CNP, calcifying nanoparticle.

\section{Possible role of CNPs in dental diseases}

There are significant reports in the literature that correlate CNPs with pathological calcifications in numerous human diseases (Table 2). Using scanning electron microscopy (SEM) and microanalysis by energy-dispersive X-ray spectroscopy, Ciftçioğlu et $\mathrm{al}^{20,21}$ demonstrated similarity between the lobular mineral formation in CNPs and pulp stone, suggesting that CNPs may be implicated in the etiology of dental pulp stones. In another study, Ciftçioğlu et $\mathrm{al}^{23}$ showed an association between CNPs and periodontal disease, their likely association with peripheral artery disease, and implications in coronary atherosclerosis. Furthermore, CNPs have been detected in high concentrations in patient serum with dental calculus and periodontitis. ${ }^{20,23,43}$

Demir also proposed a hypothesis that CNPs might be present in dental calculus and may have been responsible for the mineralization process ab initio. ${ }^{33}$ Thus, the presence of CNPs could be regarded as a factor that is likely involved in periodontal disease and dental calculus formation. ${ }^{43}$

Yang et $\mathrm{al}^{31}$ and Zeng et al ${ }^{18}$ investigated possible involvement of CNPs in dental stones by several methods: immunostaining, serology, SEM observation, and in vitro cytotoxicity, taking special precautions and utilizing treatment methods to prevent contamination of CNPs. In their study, eleven of 13 tissue samples (84.6\%) stained positive for CNP antigen immunohistochemically, whereas twelve $(92.3 \%)$ positive samples were detected by indirect immunofluorescence staining, Moreover, extracted CNPs showed concentric circles of aggregated apatite after incubation, with morphological similarity to pulp stone under SEM.

Jing et $\mathrm{al}^{29}$ hypothesized a therapeutic use of CNPs in enamel tooth repair in vitro. Others authors proposed that a gelatinous synthetic mix (free fluoride, calcium and phosphate ions, and CNPs) could be applied on a cracked tooth surface therapeutically to limit further propagation of the crack deeper into dentin. ${ }^{34}$

\section{Conclusion}

The cumulative literature evidence on CNPs since their initial description point more to the microbial nature of the particles rather than to physiological contamination. Genomic elucidation supports CNPs as living particles that do get involved positively in pathological calcifications in human organ diseases in dental pulp, salivary glands, kidneys, and arteries. Some investigators have looked into the possibility of using modified CNPs in the treatment of cracked and/or eroded teeth. ${ }^{29,34}$

\section{Disclosure}

The authors report no conflicts of interest in this work.

\section{References}

1. Kajander EO, Ciftçioğlu N. Nanobacteria: an alternative mechanism for pathogenic intra- and extracellular calcification and stone formation. Proc Natl Acad Sci U S A. 1998;95(14):8274-8279.

2. Kutikhin AG, Brusina EB, Yuzhalin AE. The role of calcifying nanoparticles in biology and medicine. Int J Nanomedicine. 2012;7: 339-350.

3. Schlieper G, Krüger T, Heiss A, Jahnen-Dechent W. A red herring in vascular calcification: 'nanobacteria' are protein-mineral complexes involved in biomineralization. Nephrol Dial Transplant. 2011;26(11): 3436-3439.

4. Kumon H, Matsumoto A, Uehara S, et al. Detection and isolation of nanobacteria-like particles from urinary stones: long-withheld data. Int J Urol. 2011;18(6):458-465.

5. Martel J, Wu CY, Young JD. Critical evaluation of gamma-irradiated serum used as feeder in the culture and demonstration of putative nanobacteria and calcifying nanoparticles. PLoS One. 2010;5(4): e10343.

6. Wu CY, Martel J, Young D, Young JD. Fetuin-A/albumin-mineral complexes resembling serum calcium granules and putative nanobacteria: demonstration of a dual inhibition-seeding concept. PLoS One. 2009; 4(11):e8058.

7. Young JD, Martel J, Young D, et al. Characterization of granulations of calcium and apatite in serum as pleomorphic mineralo-protein complexes and as precursors of putative nanobacteria. PLoS One. 2009;4(5): e5421.

8. Young JD, Martel J, Young L, Wu CY, Young A, Young D. Putative nanobacteria represent physiological remnants and culture by-products of normal calcium homeostasis. PLoS One. 2009;4(2):e4417.

9. Martel J, Young JD. Purported nanobacteria in human blood as calcium carbonate nanoparticles. Proc Natl Acad Sci U S A. 2008;105(14): $5549-5554$.

10. Raoult D, Drancourt M, Azza S, et al. Nanobacteria are mineralo fetuin complexes. PLoS Pathog. 2008;4(2):e41.

11. Urbano P, Urbano F. Nanobacteria: facts or fancies? PLoS Pathog. 2007;3(5):e55.

12. Drancourt M, Jacomo V, Lepidi H, et al. Attempted isolation of Nanobacterium sp. microorganisms from upper urinary tract stones. $J$ Clin Microbiol. 2003;41(1):368-372.

13. Cisar JO, Xu DQ, Thompson J, Swaim W, Hu L, Kopecko DJ. An alternative interpretation of nanobacteria-induced biomineralization. Proc Natl Acad Sci U S A. 2000;97(21):11511-11515.

14. Sommer AP, McKay DS, Ciftçioğlu N, Oron U, Mester AR, Kajander EO. Living nanovesicles - chemical and physical survival strategies of primordial biosystems. J Proteome Res. 2003;2(4):441-443. 
15. Kajander E, Abo K, Maniscalco B, Mezo G. The pathogenesis of vascular calcification, new clinical diagnosis markers and new curative nanobiotic treatment for reversing atherosclerosis in humans. Available from: http://nanobiotech.squarespace.com/storage/ POSTERPRESENTATIONTampere.pdf.

16. Maniloff J. Nannobacteria: size limits and evidence. Science. 1997;276(5320):1776; author reply 1777.

17. Glass JI, Assad-Garcia N, Alperovich N, et al. Essential genes of a minimal bacterium. Proc Natl Acad Sci U S A. 2006;103(2):425-430.

18. Zeng J, Yang F, Zhang W, Gong Q, Du Y, Ling J. Association between dental pulp stones and calcifying nanoparticles. Int J Nanomedicine. 2011;6:109-118

19. Kajander EO, Ciftçioğlu N, Miller-Hjelle MA, Hjelle JT. Nanobacteria: controversial pathogens in nephrolithiasis and polycystic kidney disease. Curr Opin Nephrol Hypertens. 2001;10(3):445-452.

20. Ciftçioğlu N, Ciftçioğlu V, Vali H, Kajande OE. Sedimentary rocks in our mouth: dental pulp stones made by nanobacteria. Proc SPIE. 1998;3441(7):130-135.

21. Ciftçioğlu N, Björklund M, Kuorikoski K, Bergström K, Kajander EO. Nanobacteria: an infectious cause for kidney stone formation. Kidney Int. 1999;56(5):1893-1898.

22. Hjelle JT, Miller-Hjelle MA, Poxton IR, et al. Endotoxin and nanobacteria in polycystic kidney disease. Kidney Int. 2000;57(6):2360-2374.

23. Ciftçioğlu N, McKay DS, Kajander EO. Association between nanobacteria and periodontal disease. Circulation. 2003;108(8):e58-e59.

24. MillerVM, Rodgers G, Charlesworth JA, et al. Evidence of nanobacteriallike structures in calcified human arteries and cardiac valves. $A m J$ Physiol Heart Circ Physiol. 2004;287(3):H1115-H1124.

25. Ciftçioğlu N, Vejdani K, Lee O, et al. Association between Randall's plaque and calcifying nanoparticles. Int J Nanomedicine. 2008;3(1): $105-115$.

26. Zhou Z, Hong L, Shen X, et al. Detection of nanobacteria infection in type III prostatitis. Urology. 2008;71(6):1091-1095.

27. Candemir B, Ertas FS, Kaya CT, et al. Association between antibodies against calcifying nanoparticles and mitral annular calcification. J Heart Valve Dis. 2010;19(6):745-752.

28. Hu YR, Zhao Y, Sun YW, et al. Detection of nanobacteria-like material from calcified cardiac valves with rheumatic heart disease. Cardiovasc Pathol. 2010;19(5):286-292.

29. Jing J, Lu J, Hao Y, Han Y. Nanobacteria's potential involvement in enamel repair in caries. Med Hypotheses. 2009;73(3):359-360.

30. Schwartz MA, Lieske JC, Kumar V, Farell-Baril G, Miller VM. Human-derived nanoparticles and vascular response to injury in rabbit carotid arteries: proof of principle. Int J Nanomedicine. 2008;3(2): 243-248.
31. Yang F, Zeng J, Zhang W, Sun X, Ling J. Evaluation of the interaction between calcifying nanoparticles and human dental pulp cells: a preliminary investigation. Int J Nanomedicine. 2011;6:13-18.

32. Hudelist G, Singer CF, Kubista E, et al. Presence of nanobacteria in psammoma bodies of ovarian cancer: evidence for pathogenetic role in intratumoral biomineralization. Histopathology. 2004;45(6): 633-637.

33. Demir T. Is there any relation of nanobacteria with periodontal diseases? Med Hypotheses. 2008;70(1):36-39.

34. Lin Y, Zheng R, He H, Du H, Lin Y. Application of biomimetic mineralization: a prophylactic therapy for cracked teeth? Med Hypotheses. 2009;73(4):493-494.

35. Shiekh FA, Charlesworth JE, Kim SH, et al. Proteomic evaluation of biological nanoparticles isolated from human kidney stones and calcified arteries. Acta Biomater. 2010;6(10):4065-4072.

36. Lu H, Guo YN, Liu SN, Zhang DC. Nanobacteria may be linked to calcification in placenta. Ultrastruct Pathol. 2012;36(3):160-165.

37. Kajander EO, Ciftçioğlu N, Aho K, Garcia-Cuerpo E. Characteristics of nanobacteria and their possible role in stone formation. Urol Res. 2003;31(2):47-54.

38. Mathew G, McKay DS, Ciftçioğlu N. Do blood-borne calcifying nanoparticles self-propagate? Int J Nanomedicine. 2008;3(2): 265-275.

39. Kumar V, Farell G, Yu S, et al. Cell biology of pathologic renal calcification: contribution of crystal transcytosis, cell-mediated calcification, and nanoparticles. J Investig Med. 2006;54(7):412-424.

40. Ciftçioğlu N, Miller-Hjelle MA, Hjelle JT, Kajander EO. Inhibition of nanobacteria by antimicrobial drugs as measured by a modified microdilution method. Antimicrob Agents Chemother. 2002;46(7): 2077-2086

41. Khullar M, Sharma SK, Singh SK, et al. Morphological and immunological characteristics of nanobacteria from human renal stones of a north Indian population. Urol Res. 2004;32(3):190-195.

42. Puskás LG, Tiszlavicz L, Rázga Z, Torday LL, Krenács T, Papp JG. Detection of nanobacteria-like particles in human atherosclerotic plaques. Acta Biol Hung. 2005;56(3-4):233-245.

43. Zhang SM, Tian F, Jiang XQ, et al. Evidence for calcifying nanoparticles in gingival crevicular fluid and dental calculus in periodontitis. $J$ Periodontol. 2009;80(9):1462-1470.
International Journal of Nanomedicine

\section{Publish your work in this journal}

The International Journal of Nanomedicine is an international, peerreviewed journal focusing on the application of nanotechnology in diagnostics, therapeutics, and drug delivery systems throughout the biomedical field. This journal is indexed on PubMed Central,

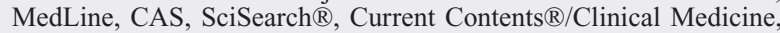

\section{Dovepress}

Journal Citation Reports/Science Edition, EMBase, Scopus and the Elsevier Bibliographic databases. The manuscript management system is completely online and includes a very quick and fair peer-review system, which is all easy to use. Visit http://www.dovepress.com/ testimonials.php to read real quotes from published authors. 